\title{
The Long-Term Effects of Adenoidectomy on Nasal Bacterial Flora in Children
}

\author{
Adenoidektominin Çocuklarda Nazal Bakteriyel Flora Üzerine Uzun Süreli \\ Etkisi
}

Sinan Uluyol* and Mehmet Zeki Erdem

Department of Otorbinolaryngology, Van Training and Research Hospital, Van, Turkey

\begin{abstract}
Objective: The purpose of this study was to investigate the long-term effect of adenoidectomy on nasal bacterial flora in children with chronically hypertrophied adenoids.

Materials and Methods: This study involved 54 consecutive children who underwent adenoidectomy due to adenoid hypertrophy. Nasal swab samples were obtained and cultured prior to the surgery and 6-months postoperatively. The pathogenic and non-pathogenic bacteria of the nasal flora were identified and microbiological results were statistically compared.
\end{abstract}

Results: Potentially pathogenic bacteria were identified in $33(61.1 \%)$ swab cultures preoperatively and in 13 $(24 \%)$ cultures $6-$ months postoperatively $(\mathrm{p}<0.001)$. The isolation rate of Staphylococcus aureus, Streptococcus pneumoniae, and Haemophilus influenzae dropped significantly in the post-operative period when compared to the pre-operative samples (all $\mathrm{p}<0.05$ ).

Conclusion: Potentially pathogenic bacteria significantly decreased following adenoidectomy and normal nonpathogenic flora in the nasal cavity has been reestablished in the long-term. Adenoidectomy alters nasal flora and thus, can be effective in preventing recurrent sinonasal and/or middle ear infections in children.

Key Words: Adenoids, bacteria, culture, flora, microorganism, pathogen

\section{Introduction}

Upper respiratory tract infections including sinonasal and middle ear infections are the most common infectious diseases in children. They are generally caused by the potentially pathogenic bacteria of the nasal and nasopharyngeal flora. The exact mechanisms that cause these bacteria to become invasive and to overcome normal flora are still unclear. Adenoid hypertrophy may influence the

\section{ÖZET}

Amaç: Bu çalışmanın amacı, kronik adenoid hipertrofisi olan çocuklarda, adenoidektominin nazal bakteriyel flora üzerine uzun vadeli etkisini araştırmaktır.

Gereç ve Yöntem: Bu çalışmada, adenoid hipertrofisi nedeniyle adenoidektomi yapılan 54 ardişık çocuk hasta değerlendirildi. Çalışmaya alınan hastalarda, operasyon öncesi ve 6 ay post-operatif dönemde nazal sürüntü örnekleri alınarak ve kültür çalışması yapıldı. Nazal floradaki patojenik ve patojenik olmayan bakteriler belirlenerek, mikrobiyolojik sonuçlar istatistiksel olarak karşılaştırıldı.

Bulgular: Potansiyel patojen bakteriler pre-operatif 33 (\%61.1) nazal kültürlerde izole edilirken, post-operatif 13 $(\% 24)$ kültürde tespit edildi $(\mathrm{p}<0.001)$. Ameliyat öncesi sürüntü örneklerine göre Staphylococcus aureus, Streptococcus pneumoniae ve Haemophilus influenzae izolasyon oranı post-operatif dönemde anlamlı olarak azaldı (tüm $\mathrm{p}<0.05$ ).

Sonuç: Potansiyel patojen mikroorganizmalar adenoidektomi sonrası uzun dönemde anlamlı derecede azalmış ve patojen olmayan normal flora bakterilerinde artış izlenmiştir. Adenoidektomi, nazal florayı uzun vadede olumlu yönde etkileyerek çocuklarda tekrarlayan sinonazal ve /veya orta kulak enfeksiyonlarının önlenmesinde etkili olabilir.

Anahtar Kelimeler: Adenoid, bakteri, kültür, flora, mikroorganizma, patojen

balance between the normal nasopharyngeal flora and the pathogenic bacteria. Previously adenoid tissue has been shown to cause colonization of pathogenic bacteria in the nasopharynx, and this situation has been suggested to be the reason of recurrent sinonasal and middle ear infections during childhood (1-3).

The adenoids are lymphoid tissue, situated in the posterior wall of the nasopharynx. Adenoidectomy (surgical removal of the adenoid tissue) is one of the most common surgeries for children presenting to

*Sorumlu Yazar: Sinan Uluyol MD. Van Eğitim ve Araştrıma Hastanesi, Kulak Burun Boğaz Kliniği, Van, İpekyolu Caddesi, Hava Yolu Kavşağ1 1. Kilometre 65300 Edremit Van/Türkiye, Telefon: +9 (0432) 2157601 /3420, Faks: +9 (0432) 2121954

E-mail: sinanuluyol@hotmail.com

Geliş Tarihi: 02.06.2016, Kabul Tarihi: 28.11.2016 
ear, nose, and throat physicians and extremely successful procedure when used to treat upper airway obstruction (4).

The objective of this study was to assess the longterm effect of adenoidectomy on nasal bacterial flora in children with chronically hypertrophied adenoids.

\section{Material and Methods}

This study involved 54 consecutive children (23 female and 31 male) who underwent adenoidectomy due to adenoid hypertrophy from January 2015 to May 2016. All patients were aged from 2 to 13 years (mean age $5.9 \pm 1.8$ years).

All participants were evaluated with the same systematic protocol. For the diagnosis of presence or absence of adenoid hypertrophy, detailed otorhinolaryngologic examination, endoscopic nasopharyngeal examination, and lateral radiographs of the nasopharynx were used. The patients included in the study did not have any upper respiratory tract infection, or antimicrobial treatment 4 weeks before the operation. Patients who underwent other surgeries (e.g. tonsillectomy) during the same operation were also excluded.

All patients were operated by the same surgeon using the curettage method under general anaesthesia. At the beginning of the operation, nasal swab samples were taken by firmly rubbing the nasal septum and inferior turbinate approximately $2 \mathrm{~cm}$ distance into the nares under the endoscope guidance, and samples were immediately cultured on chocolate agar and blood agar plates. Six months after the intervention, nasal swab samples were taken by the same procedure when the patient was free of disease and cultured again.

\section{Streptococcus pyogenes, Streptococcus} pneumoniae, Haemophilus influenzae, Staphylococcus aureus, Moraxella catarrhalis, Moraxella lacunata and Prevotella melaninogenica were evaluated as potentially pathogenic bacteria and Staphylococcus epidermidis, Streptococcus sanguis, Streptococcus salivarius, Peptostreptococcus micros, Veillonella parvula, Neisseria sicca, and Streptococcus agalactiae were evaluated as bacteria for the normal flora.

The microbiological results were compared by using the Fischer exact test (SPSS software, ver. 23.0 for Windows; SPSS Inc., Chicago, IL, USA). A p-value $<0.05$ was considered to indicate statistical significance.

This study adhered to the guidelines of the Helsinki Declaration of the World Medical Association and was approved by the Research Ethics Committee of our Tertiary Referral Center. Written informed consent was obtained from the parents of all participants prior to the study.

\section{Results}

Potentially pathogenic bacteria were identified in $33(61.1 \%)$ swab cultures preoperatively and in 13 (24\%) cultures $6-$ months postoperatively. There was a significant difference between the pre- and post-operative isolation rate of the potentially pathogenic bacteria $(\mathrm{p}<0.001)$. The most frequently encountered bacteria from the pathogenic group were Streptococcus pneumoniae, Staphylococcus aureus, and Haemophilus influenzae respectively. The isolation rate of Staphylococcus aureus, Streptococcus pneumoniae, and Haemophilus influenzae dropped significantly in the postoperative period when compared to the preoperative samples (all $\mathrm{p}<0.05)$. Table 1 presents the data of potential pathogenic group.

\section{Discussion}

The human nasopharynx is a natural reservoir for several bacterial species, also including potential pathogens. Bacterial carriage varies across the different subgroups. Streptococcus pneumoniae,

Table 1. The alterations of potential pathogenic bacteria after adenoidectomy

\begin{tabular}{lccr}
\hline & \multicolumn{2}{c}{ Number of culture-positive specimens } \\
\hline & $\begin{array}{c}\text { Pre-operative } \\
(\mathrm{n}=33)\end{array}$ & $\begin{array}{c}\text { 6-months post-operative } \\
(\mathrm{n}=13)\end{array}$ & $\mathrm{p}$ \\
\hline Streptococcus pneumoniae & 10 & 4 & $<0.001$ \\
Staphylococcus aureus & 9 & 4 & 0.001 \\
Haemophilus influenzae & 7 & 4 & 0.012 \\
Moraxella catarrhalis & 4 & 1 & 0 \\
Moraxella lacunata & 2 & 0 & \\
Prevotella melaninogenica & 1 & -2 & \\
\hline
\end{tabular}

Van Tip Derg Cilt:24, Say1:2, Nisan/2017 
Staphylococcus aureus, and Haemophilus influenzae are common in children with sinonasal symptoms, whereas Moraxella catarrhalis is not common in children with diverse symptoms related to the adenoid and/or tonsils. Neisseria species, Peptostreptococcus species, and alphahemolytic streptococci appear to make up the greatest part of the non-pathogenic (normal) flora of the nasopharynx $(3,5)$.

As stated previously the hypertrophied and inflamed adenoids are associated with a potentially pathogenic mixed bacterial flora and this situation has been suggested to be the reason of recurrent sinonasal and middle ear infections in childhood (4). Previously it has been proposed that surgical removal of hypertrophied and infected tonsils or adenoids might have a particular impact on the bacteriology of the upper respiratory tract system (6). Manoles et al. (7) showed that after surgical treatment (adenotonsillectomy) the pathogenic microorganisms were quantitatively reduced and normal flora bacteria significantly increased. Talaat et al. (8) reported that the isolation rate of potentially pathogenic microorganisms decreased markedly following adenoidectomy, while the normal inhabitant organisms showed notable increase in their numbers. Callejo et al. (9) concluded that tonsillectomy and adenoidectomy decreased the colonization of abnormal oropharyngeal and nasopharyngeal microbial flora. In the studies above, the postoperative swabs were taken after a short period, varying from 10 days to one month unlike the present study. Thus, our study is the first one to present the long-term effects of adenoidectomy on bacterial nasal flora in children.

In our study, we aimed to evaluate the effects of hypertrophied adenoids on nasal bacterial flora and the alterations of nasal flora after surgical treatment (adenoidectomy). Our results showed that carriage of potential pathogens decreased, specifically Streptococcus pneumoniae, Staphylococcus aureus, Haemophilus influenzae, and normal nonpathogenic flora in the nasal cavity is reestablished in the long-term. On the basis of the bacteriologic results of this study, adenoidectomy would have beneficial effects on relieving upper airway obstruction and also reducing sinonasal and middle ear infections. In case of the failure of antimicrobial treatment in sinonasal and/or middle ear infections, adenoidectomy should be seriously considered.

\section{References}

1. Lee D, Rosenfeld RM. Adenoid bacteriology and sinonasal symptoms in children. Otolaryngol Head Neck Surg 1997; 116(3): 301-307.

2. Tomonaga K, Kurono Y, Chaen T, Mogi G. Adenoids and otitis media with effusion: nasopharyngeal flora. Am J Otolaryngol 1989; 10(3): 204-207.

3. Dhooge I, van Damme D, Vaneechoutte $M$, Claeys G, Verschraegen G, van Cauwenberge P. Role of nasopharyngeal bacterial flora in the evaluation of recurrent middle ear infections in children. Clin Microbiol Infect 1999; 5(3): 530534.

4. Brietzke SE, Gallagher D. The effectiveness of tonsillectomy and adenoidectomy in the treatment of pediatric obstructive sleep apnea/hypopnea syndrome: a meta-analysis. Otolaryngol Head Neck Surg 2006; 134(6): 979984.

5. Ingvarsson L, Lundgren K, Ursing J. The bacterial flora in the nasopharynx in healthy children. Acta Otolaryngol (Stockh) 1982; 386: 94-96.

6. Aarts JW, van den Aardweg MT, Rovers MM, Bonten MJ, Schilder AG. Alterations in the nasopharyngeal bacterial flora after adenoidectomy in children: a systematic review. Otolaryngol Head Neck Surg 2010; 142(1): 15-20.

7. Manolis E, Tsakris A, Kandiloros D, Kanellopoulou M, Malamou-Lada E, Ferekidis E, et al. Alterations to the oropharyngeal and nasopharyngeal microbial flora of children after tonsillectomy and adenoidectomy. J Laryngol Otol 1994; 108(9): 763767.

8. Talaat AM, Bahgat YS, el-Ghazzawy E, Elwny S. Nasopharyngeal bacterial flora before and after adenoidectomy. J Laryngol Otol 1989; 103(4): 372-374.

9. García Callejo FJ, Vlert Vila MM, Orts Alborch MH, Pardo Mateu L, Marco Algarra J. Effects of adenoidectomy and tonsillectomy on the bacterial flora of the nose and oropharynx. Acta Otorrinolaringol Esp 1997; 48(6): 467-472. 